\title{
The analysis of air pollution based on laser beam photo
}

\section{Ocena zanieczyszczenia powietrza na podstawie zdjęcia wiązki lasera}

\author{
Anna Pawelec, Rafał Maksim* , Maria Skublewska-Paszkowska \\ Department of Computer Science, Lublin University of Technology, Nadbystrzycka 36B, 20-618 Lublin, Poland
}

\begin{abstract}
The article presents a comparison of original methods of air quality measurement with a professional device Air Smartbox v. 1.2. The methodology consisted of laser beam analysis from the device. To enable detailed photo analysis for the research, an Android mobile application was developed. The OpenCV library was used to process the images. In the article, the hypothesis was put forward that the method using a binary threshold with a threshold value of 50 allows to obtain results closest to those of the station. This hypothesis was confirmed by the results of the experiments.

Keywords: air pollution; Android; OpenCV; image processing; Fourier Transform
\end{abstract}

\section{Streszczenie}

Artykuł przedstawia porównanie autorskich metod pomiaru jakości powietrza z profesjonalnym urządzeniem Air Smartbox v. 1.2. Metody polegają na analizie zdjęć wiązki lasera w zanieczyszczonym powietrzu. W celu przeprowadzenia badań została zaimplementowana aplikacja mobilna, dedykowana na system operacyjny Android, która umożliwia wykonanie zdjęć oraz ich późniejszą obróbkę i analizę. Do przetwarzania obrazów zastosowano bibliotekę OpenCV. W artykule postawiono hipotezę, że metoda wykorzystująca progowanie binarne $\mathrm{z}$ wartością progowania wynoszącą 50 pozwala uzyskać wyniki najbardziej zbliżone do wyników ze stacji. Hipoteza ta została potwierdzona uzyskanymi wynikami badań.

Stowa kluczowe: zanieczyszczenie powietrza; Android; OpenCV; przetwarzanie obrazów; Transformata Fouriera

${ }^{*}$ Corresponding author

Email address: rafal.maksim@outlook.com (R. Maksim)

CPublished under Creative Common License (CC BY-SA v4.0)

\section{Wstęp}

Wraz ze wzrostem świadomości o zanieczyszczeniu powietrza powstają kolejne metody do jego pomiaru. W związku z tym wzrosła również popularność urządzeń mierzących stężenia tych zanieczyszczeń. Niestety większość profesjonalnych urządzeń jest droga, więc na zakup takiego urządzenia może sobie pozwolić małe grono użytkowników. Autorzy tej pracy postawili sobie za cel stworzenie taniego, ale profesjonalnego sposobu pomiaru jakości powietrza dostępnego $\mathrm{w}$ miejscu przebywania użytkownika. W tym celu została zaimplementowana aplikacja mobilna dedykowana na system Android, umożliwiająca analizę zanieczyszczenia powietrza na podstawie analizy zdjęcia wiązki lasera.

Autorzy postawili hipotezę, że metoda wykorzystująca progowanie binarne $\mathrm{z}$ wartością progowania wynoszącą 50 (opisywana również jako Binary threshold 50) pozwala uzyskać wyniki najbardziej zbliżone do wyników ze stacji pomiarowej. W niniejszym artykule zostaną przedstawione wyniki udowadniające to założenie.

\section{Przetwarzanie i filtrowanie obrazu}

\subsection{Filtrowanie obrazu}

Obraz, czyli macierz, którą komputer odczytuje jako pewną siatkę liczb [1] może być poddany przetwarzaniu i filtracji. Pozwala to na szeroki zakres rozpoznawania i przetwarzania informacji zawartych na obrazie. Filtracją nazywa się pewną funkcję matematyczną, która pozwoli na przekształcenie obrazu, zwykle celem po- lepszenia jego jakości czy ostrości [2]. Filtry można podzielić na liniowe oraz nieliniowe. Prostsze w wykonaniu są filtry liniowe, ale są one uboższe w możliwości niż filtry nieliniowe. Przykładem filtru liniowego może być średnia arytmetyczna wygładzająca obraz poprzez uśrednianie punktów sąsiedztwa, a nieliniowego - metoda Perony-Malika, używająca współczynnika wpływającego na stopień rozmycia w zależności od estymatora krawędzi [2]. Filtr uśredniający posiada jednak wady w postaci zbyt dużego rozmycia obrazu.

Innym filtrem nieliniowym jest filtr Laplace'a, który ma za zadanie wyostrzenie obrazu. Pozwala on na wydobycie z obrazu małych punktów, jednakże jest ona bardzo czuła na szumy. Opisane wyżej filtry są szeroko stosowane w analizie obrazów.

\subsection{Wykrywanie krawędzi}

Do wykrywania krawędzi warto rozważać użycie jednego z algorytmów detekcji krawędzi. Są to między innymi filtry Sobela, Robertsa czy Prewitta. Bardzo dokładnym filtrem jest metoda opisana przez Johna F. Canny’ego, która spełnia kryteria [2]:

- dobrej detekcji - znikome prawdopodobieństwo zaznaczeń punktów niebędących krawędzią obrazu;

- dobrej lokalizacji - punkty powinny być możliwie najbliżej krawędzi obrazu;

- $\quad$ pojedynczej odpowiedzi - nie powinny zostać zaznaczone fałszywe krawędzie, zaznaczenie jest tylko jedno. 
Canny przedstawił sposób rozwiązania do tego podejścia, polegające na sekwencji poniższych operacji [2]:

1. zastosowanie filtru gaussowskiego celem redukcji szumów;

2. detekcja krawędzi z użyciem operatorów gradientu i określenie orientacji krawędzi;

3. usunięcie pikseli o wartości niższej niż maksymalna;

4. budowa histogramu dla obrazu konturu (konstrukcja krawędzi i progowanie histogramu).

\subsection{Dyskretna transformata Fouriera}

Francuski matematyk Jean Baptiste Joseph Fourier przedstawił wiele pomysłów wykorzystywanych w dziedzinach przetwarzania sygnałów oraz obrazu [3]. Obraz cyfrowy jest zbiorem liczb - uporządkowanym, zatem jest to po prostu ciąg dwuwymiarowy o wartościach rzeczywistych [4]:

$\mathrm{L}=\{\mathrm{L}(\mathrm{m}, \mathrm{n}) \in \Re: \mathrm{m}=0,1, \ldots, \mathrm{M}=-1 ; \mathrm{n}=0,1, \ldots, \mathrm{N}-1\}$

- założono, że długość ciągu wynosi N, zatem indeksy $\mathrm{k}$ będą równe od 0 do $\mathrm{N}-1$;

- $j=\sqrt{-1}$.

W związku z faktem, że obraz jest pewnym uporządkowanym zbiorem liczb można użyć dyskretnej transformacji Fouriera prostym przekształceniem przedstawionym poniżej [4]:

$F(i, k)=\beta_{L} \cdot \sum_{m=0}^{M-1} \sum_{n=0}^{N-1} L(m, n) \cdot \exp \left(\frac{-j \cdot 2 \cdot \pi \cdot m \cdot i}{M}\right) \cdot \exp \left(\frac{-j \cdot 2 \cdot \pi \cdot n \cdot k}{N}\right)$

gdzie:

- $\beta_{\mathrm{L}}$ współczynnik dla transformacji w przód;

- $\beta_{\mathrm{F}}$ dla transformacji odwrotnej.

Ponad to, współczynniki te określane są jako [4]:

$$
\beta_{\mathrm{L}}=1 ; \beta_{\mathrm{F}}=\frac{1}{\mathrm{M} \cdot \mathrm{N}}
$$

Jeśli poniższe zależności zostaną spełnione [4]:

$$
\beta_{L} \cdot \beta_{F}=\frac{1}{M \cdot N}
$$

$\begin{aligned} & \beta_{L} \cdot \beta_{F}=\frac{1}{\mathrm{M} \cdot \mathrm{N}} \\ & \text { to możliwe jest wykonanie odwrotnej transformacji }\end{aligned}$ Fouriera, określonej wzorem [4]:

$$
\mathrm{L}(\mathrm{m}, \mathrm{n})=\beta_{\mathrm{F}} \cdot \sum_{\mathrm{i}=0}^{\mathrm{M}-1} \sum_{\mathrm{k}=0}^{\mathrm{N}-1} \mathrm{~F}(\mathrm{i}, \mathrm{k}) \cdot \exp \left(\frac{\mathrm{j} \cdot 2 \cdot \pi \cdot \mathrm{m} \cdot \mathrm{i}}{\mathrm{M}}\right) \cdot \exp \left(\frac{\mathrm{j} \cdot \mathrm{\cdot} \cdot \mathrm{\pi} \cdot \mathrm{n} \cdot \mathrm{k}}{\mathrm{N}}\right)
$$

W pracy „Wykorzystanie transformacji Fouriera do filtracji szumu informacyjnego $\mathrm{z}$ obrazów fotolotniczych" [5] przedstawiono użycie transformacji Fouriera. Autor wykorzystał niedoskonałe panchromatyczne zdjęcia lotnicze zawierające różne szumy i zniekształcenia. Celem ich usunięcia, użył dyskretnej transformacji Fouriera i usunął $\mathrm{z}$ widma pewne elementy. Następnie zastosował odwrotną transformatę dla nowej funkcji widma. Jako efekt przeprowadzonego badania uzyskał on satysfakcjonujący wynik dla dwóch $\mathrm{z}$ trzech obrazów, ponieważ po zastosowaniu wyżej wymienionych metod ich jakość poprawiła się, a szumy zostały znacząco osłabione. Wynik ten utwierdził autorów niniejszego artykułu w przekonaniu, że dyskretna transformacja Fouriera będzie odpowiednia do zaimplementowania w wymyślonych przez nich metodach.

\subsection{Splot}

Innym możliwym do zastosowania podejściem jest splot. Filtr odczytuje piksele z macierzy kolejno zaczynając od lewej strony do prawej oraz od góry do dołu. W przypadku symetrycznego jądra środek macierzy powinien zachodzić na sąsiednie piksele. Każdy element macierzy zostaje pomnożony przez wartość piksela, z którą się pokrywa, natomiast wartości wynikowe zostają zsumowane. Wynik jest nową wartością dla elementu pokrywającego się ze środkiem macierzy. Dla przypadku niesymetrycznego jądra, środek macierzy zostaje obrócony przed wykonaniem funkcji splotu.

\subsection{Progowanie}

Następną możliwością obróbki graficznej jest progowanie, które ma na celu podział obrazu [6]. Ustalana jest wartość progowa, a każdy punkt zostaje z nią porównany. Obraz po binaryzacji jest podzielony na części, z których jedna składa się z barwy białej, a druga czarnej [2].

\section{Aplikacja mobilna}

Aplikacja mobilna stworzona przez autorów zaprojektowana została na system Android w wersji Oreo (8.0) lub wyższej. Wykorzystuje ona bibliotekę OpenCV [7]. Użytkownik po wykonaniu zdjęcia lub serii zdjęć może wyliczyć poziom zanieczyszczenia powietrza, sprawdzić archiwalne wyniki oraz dostosować wartość progowania, wybrać metodę analizy i wpisać miejsce pomiaru.

Na rysunku 1 przedstawiono wygląd strony głównej aplikacji. W celu analizy zdjęcia należy wcisnąć przycisk Analyze. Następnie należy sprawdzić, czy wiązka lasera jest dobrze widoczna w kadrze i zrobić zdjęcie wiązki lasera (rysunek 5) oraz potwierdzić wykonane zdjęcie do analizy (rysunek 3). Rysunek 4 przedstawia zdjęcie po obróbce oraz wynik otrzymany z analizy.

Zdjęcie, które ma być poddane analizie musi spełniać poniższe kryteria:

- $\quad$ ostrość musi być ustawiona dokładnie na wiązkę lasera;

- wiązka lasera musi przebiegać możliwie równolegle do poziomych krawędzi kadru;

- nie powinno posiadać innych źródeł światła;

- powinno zostać wykonane przy użyciu statywu i zdalnego wyzwalacza.

Po spełnieniu powyższych kryteriów może zostać ono poddane obróbce graficznej. Na rysunku 5 przedstawiono przykład poprawnie wykonanego zdjęcia.

Zdjęcie może być przeanalizowane jedną $\mathrm{z}$ trzech metod:

- progowanie;

- dyskretna transformacja Fouriera oraz progowanie;

- zastosowanie splotu oraz progowania. 


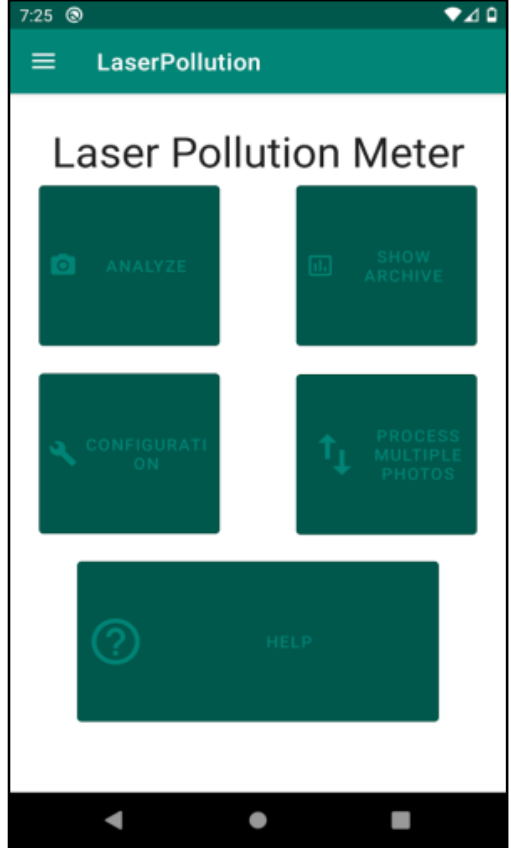

Rysunek 1: Strona główna aplikacji

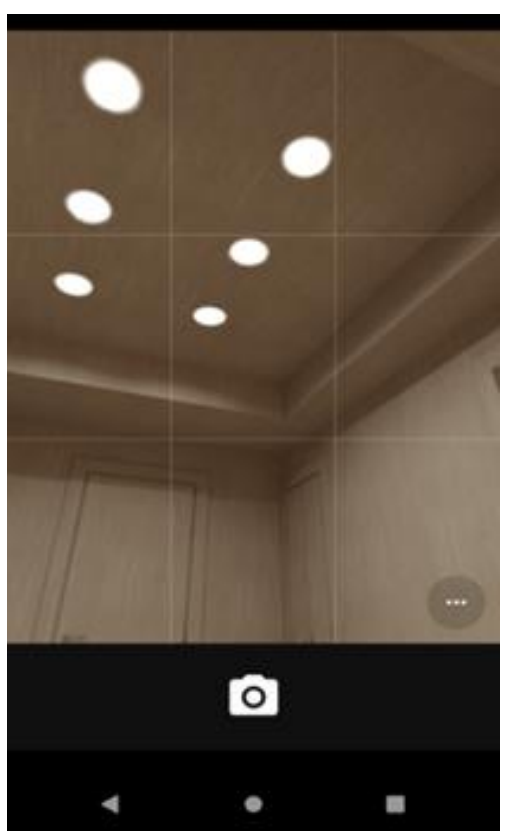

Rysunek 2: Podgląd aparatu przed wykonaniem zdjęcia

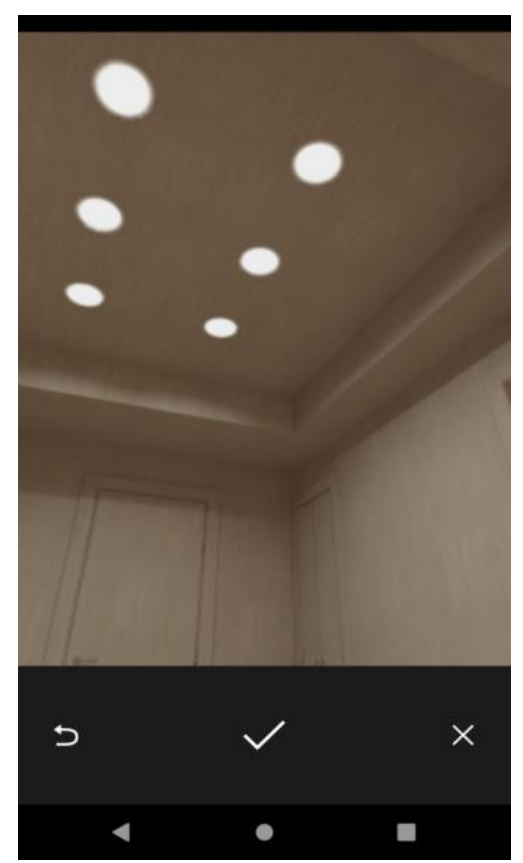

Rysunek 3: Ekran zatwierdzania zdjęcia

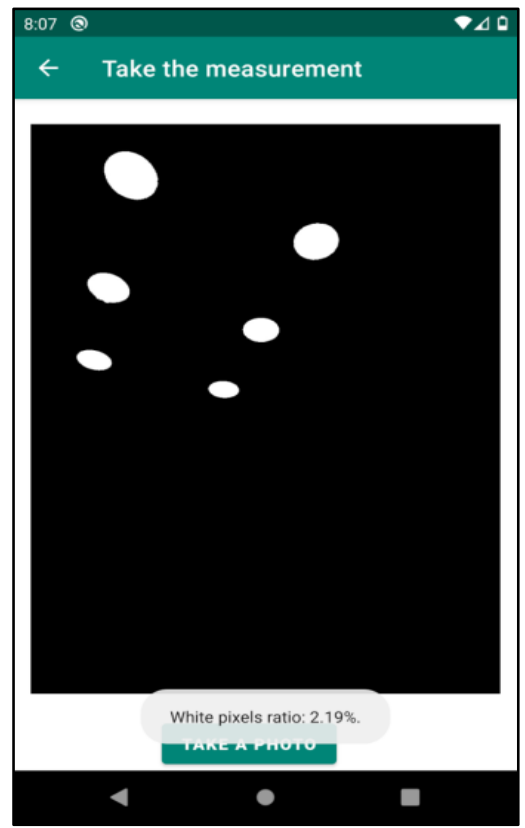

Rysunek 4: Wyświetlenie obrobionego zdjęcia i komunikatu

\section{Obróbka graficzna wykonanego zdjęcia}

Pierwsza dostępną metodą jest progowanie binarne. Autorzy zdecydowali się na wykorzystanie dwóch wartości progowania: 50 i 100. Zdjęcie jest poddawane działaniu tej metody.

Następną metodą, której można użyć do analizy zdjęcia jest dyskretna transformacja Fouriera i progowanie. Po użyciu dyskretnej transformacji Fouriera na zdjęcie należy nałożyć maskę celem usunięcia niskich częstotliwości. Następnie wykonywana jest odwrotna transformata Fouriera, co przywróci oryginalny format zdjęcia. Na końcu tak przetworzone zdjęcie poddaje się operacji progowania. 
Ostatnią możliwą do wykonania metodą analizy jest metoda używająca filtra górnoprzepustowego i progowania. Wykorzystano w tym celu maskę [8] o wymiarach $3 \times 3$ przedstawioną na rysunku 6 .

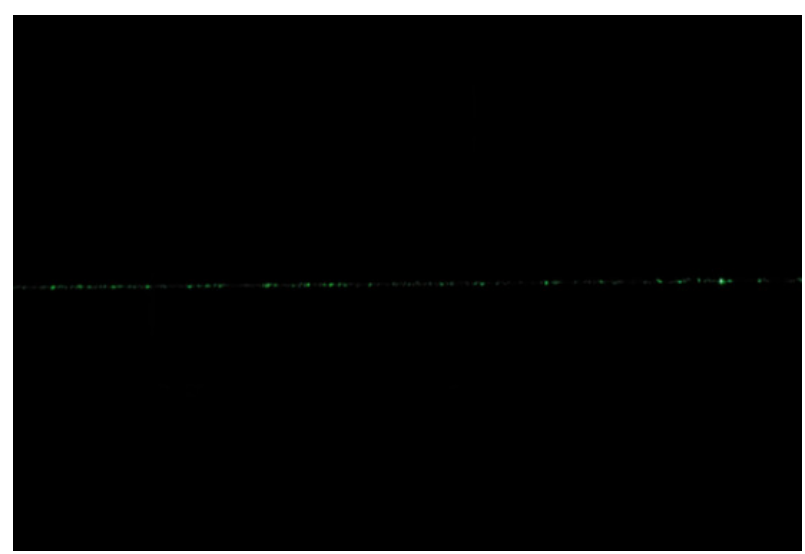

Rysunek 5: Poprawnie wykonane zdjęcie

$$
\left[\begin{array}{ccc}
0,17 & 0,67 & 0,17 \\
0,67 & -3,33 & 0,67 \\
0,17 & 0,67 & 0,17
\end{array}\right]
$$

Rysunek 6: Maska o wymiarach 3x3

Zdjęcie jest przetwarzane $\mathrm{z}$ wykorzystaniem kernela (rysunek 6) i zostaje poddane progowaniu, czyli pierwszej opisanej metodzie.

Po wykonaniu obróbki zdjęcia można zliczyć wszystkie białe piksele i podzielić ich liczbę przez liczbę wszystkich pikseli na zdjęciu, a następnie pomnożyć przez 100 , co pozwoli na uzyskanie procentowej zawartości cząsteczek w powietrzu. Opisane tutaj białe piksele to rozbłyski świetlne, czyli cząsteczki zanieczyszczeń zawieszonych w powietrzu, które odbiły światło lasera.

\section{Metoda badawcza}

\subsection{Opis stanowiska}

Rysunek 7 przedstawia stanowisko badawcze. Na stoli$\mathrm{ku}$ została umieszczona stacja pomiarowa oraz laser ustawiony na statywie w taki sposób, aby wiązka lasera przebiegała równolegle do podłoża. W odległości $70 \mathrm{~cm}$ od urządzenia pomiarowego i statywu z laserem został ustawiony telefon, również na statywie.

Telefon użyty do doświadczenia to LG V30, który posiada aparat fotograficzny o następujących parametrach:

- $\quad$ kąt widzenia: $71^{\circ}$;

- maksymalna rozdzielczość zdjęcia: $16 \mathrm{Mpx}$;

- maksymalna przysłona f/1.6;

- optyczna stabilizacja obrazu;

- $\quad$ stała ogniskowa $30 \mathrm{~mm}$.

Podczas wykonywania zdjęć aparat miał ręcznie ustawioną ostrość oraz pracował w trybie manualnym z następującymi wartościami:

- $\quad$ wartość przysłony: f/1.6;

- rozdzielczość zdjęcia: $16 \mathrm{Mpx}$;

- czułość matrycy ISO: 100;
- $\quad$ czas naświetlania: $1 \mathrm{~s}$.

Do eksperymentu wykorzystano laser o następujących parametrach:

- maksymalna moc wyjściowa mniejsza niż $5000 \mathrm{~mW}$;

- długość fali wynosi $532 \mathrm{~nm} \pm 10 \mathrm{~nm}$.

Stacja pomiaru, jako urządzenie referencyjne, użyta do eksperymentu to Air Smartbox v. 1.2. Jest to urządzenie między innymi do pomiaru stężenia pyłów zawieszonych PM2,5, PM10 w powietrzu, mierzące stężenie zanieczyszczenia co pół minuty.

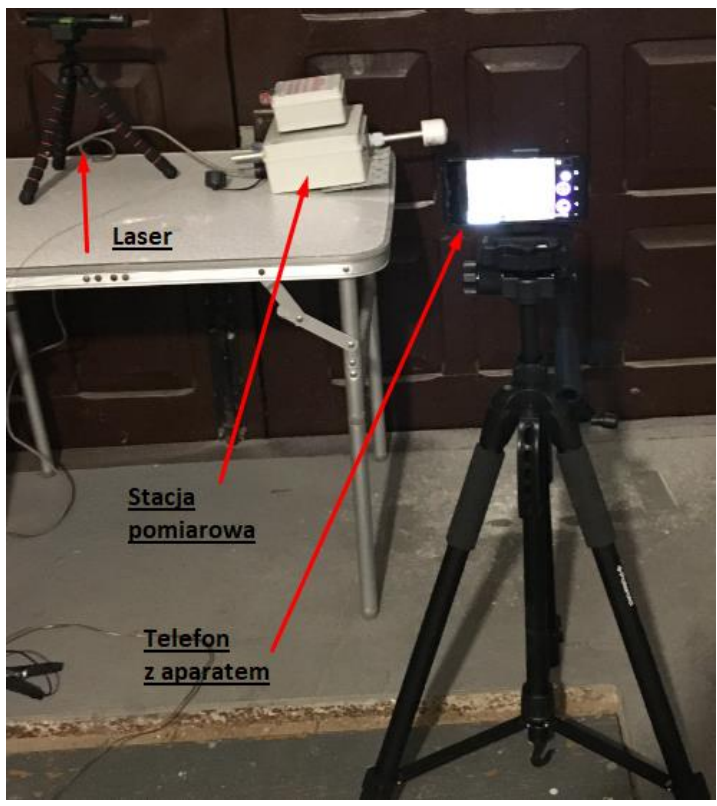

Rysunek 7: Stanowisko eksperymentu

\subsection{Przeprowadzenie badania}

Badanie zakładało przeprowadzenie dwóch eksperymentów, które odbyły się w późnych godzinach wieczornych. W pomieszczeniu, w którym były wykonywane, zostało zgaszone światło, aby wiązka lasera była dobrze widoczna. W tym czasie odbywały się w nim prace remontowe, co pozwoliło na uzyskanie zmiennego zanieczyszczenia powietrza.

Każdy z eksperymentów polegał na wykonywaniu zdjęcia wiązki lasera co pół minuty przez około 30 minut zdalnym wyzwalaczem migawki. W rezultacie otrzymano 63 zdjęcia dla pierwszego eksperymentu i 71 dla drugiego, które następnie zostały przetworzone przy użyciu aplikacji mobilnej, wykorzystując funkcję przetwarzania sekwencyjnego plików oraz wcześniej opisane metody.

\subsection{Analiza porównawcza}

Porównanie wyników badań polega na:

- wzrokowym porównaniu wykresów wyników badań z wynikami ze stacji pomiarowej;

- $\quad$ wykonaniu statystyki opisowej;

- analizie pochodnych różnic zbiorów;

- $\quad$ analizie korelacji Kendalla. 


\subsection{Wyniki i ich analiza}

W tabeli 1 przedstawiono statystykę opisową otrzymanych wyników dla eksperymentu pierwszego, zaś w tabeli 2 dla eksperymentu drugiego.

Przyjęto następujące nazewnictwo:

- Binary threshold 100 oznacza metodę progowania binarnego z wartością progowania równą 100;

- Binary threshold 50 oznacza metodę progowania binarnego z wartością progowania równą 50;

- Fourier 100 oznacza metodę z transformatą Fouriera, progowaniem i wartością progowania równą 100 ;

- Fourier 50 oznacza metodę z transformatą Fouriera, progowaniem i wartością progowania równą 50 ;

- Kernel 100 oznacza metodę z kernelem, progowaniem i wartością progowania równą 100;

- Kernel 50 oznacza metodę z kernelem, progowaniem i wartością progowania równą 50 .

Końcówki Ex1 i Ex2 oznaczają odpowiednio eksperyment 1 . i eksperyment 2.

Każdy wykres zbioru danych może zostać w pewien sposób zmodyfikowany. Jedną z najprostszych operacji jest przesunięcie takiego wykresu o zadaną wartość względem osi OY. Przykładowo, prosty wykres funkcji liniowej $\mathrm{y}=\mathrm{x}$ można przekształcić tak, aby przecinał oś OY w punkcie $(0,1)$ zamiast w $(0,0)$. W tym celu należy przesunąc wykres o 1 jednostkę w górę, co realizowane jest przez dodanie jedności do wzoru funkcji. Tym samym nowy wzór funkcji będzie wyglądał następująco: $\mathrm{y}=\mathrm{x}+1$.

Zakładając, że funkcje $\mathrm{f}(\mathrm{x})=\mathrm{x}$ oraz $\mathrm{g}(\mathrm{x})=\mathrm{x}+1$ zostaną nałożone na ten sam układ współrzędnych, można łatwo zaobserwować, że oba wykresy zmieniają się w identyczny sposób. Skutkuje to tym, że dla każdego punktu na osi OX różnica $\mathrm{g}(\mathrm{x})$ - $\mathrm{f}(\mathrm{x})$ będzie taka sama. $\mathrm{Na}$ tej podstawie można stworzyć nową funkcję $\mathrm{h}(\mathrm{x})=$ $\mathrm{g}(\mathrm{x})$ - $\mathrm{f}(\mathrm{x})$, która będzie funkcją stałą. Wnioskując, jeżeli wartości dwóch równolicznych zbiorów danych zmieniają się $\mathrm{w}$ taki sam sposób to zbiór powstały $\mathrm{z}$ odjęcia ich od siebie powinien być funkcją stałą

Rysunki 8,9 oraz 10 przedstawiają wykresy pochodnych różnic wartości pomiędzy pomiarami.

Przy użyciu korelacji Kendalla sprawdzono, w jakim stopniu dane pomiarowe uzyskane przy użyciu metod $\mathrm{z}$ aplikacji mobilnej są skorelowane $\mathrm{z}$ danymi pomiarowymi ze stacji. Wyniki liczbowe przedstawiono w tabeli 3, zaś wykres na rysunku 11 .

Tabela 1: Uzyskane wyniki dla eksperymentu 1

\begin{tabular}{|c|c|c|c|c|c|c|c|}
\hline & $\begin{array}{l}\text { Fourier } \\
\text { Transform } \\
50\end{array}$ & $\begin{array}{l}\text { Fourier } \\
\text { Transform } \\
100\end{array}$ & $\begin{array}{l}\text { Binary } \\
\text { Threshold } 50\end{array}$ & $\begin{array}{l}\text { Binary } \\
\text { Threshold } 100\end{array}$ & Kernel 50 & Kernel 100 & $\begin{array}{l}\text { Stacja } \\
\text { pomiarowa }\end{array}$ \\
\hline $\begin{array}{l}\text { Wartość } \\
\text { minimalna }\end{array}$ & 0.070162 & 0.00436343 & 0.0185931 & 0.00214039 & 0.0172338 & 0.00280464 & $\begin{array}{l}1.0310000000000 \\
00 \mathrm{e}+02\end{array}$ \\
\hline $\begin{array}{l}\text { Wartość } \\
\text { maksymalna }\end{array}$ & 99.9951 & 0.169855 & 0.235479 & 0.100555 & 0.232644 & 0.104159 & $\begin{array}{l}5.6140000000000 \\
00 \mathrm{e}+02\end{array}$ \\
\hline Mediana & 99.7561 & 0.0419097 & 0.0794772 & 0.0215023 & 0.0732652 & 0.0216745 & $1.207000000 \mathrm{e}+02$ \\
\hline Średnia & $\begin{array}{l}73.05014608 \\
4127\end{array}$ & $\begin{array}{l}0.0492879987 \\
30159\end{array}$ & $\begin{array}{l}0.0870648857 \\
14286\end{array}$ & $\begin{array}{l}0.02637485460 \\
3175\end{array}$ & $\begin{array}{l}0.0830305238 \\
09524\end{array}$ & $\begin{array}{l}0.027283469841 \\
27\end{array}$ & $\begin{array}{l}1.3728253968253 \\
97 e+02\end{array}$ \\
\hline Moda & 0.070162 & 0.00436343 & 0.0678773 & 0.00214039 & 0.0172338 & 0.00280464 & $\begin{array}{l}1.0480000000000 \\
00 \mathrm{e}+02\end{array}$ \\
\hline $\begin{array}{l}\text { Odchylenie } \\
\text { standardowe }\end{array}$ & $\begin{array}{l}44.21036810 \\
6011394\end{array}$ & $\begin{array}{l}0.0337866084 \\
32889\end{array}$ & $\begin{array}{l}0.0389640211 \\
9592\end{array}$ & $\begin{array}{l}0.01937482884 \\
9719\end{array}$ & $\begin{array}{l}0.0395345029 \\
75415\end{array}$ & $\begin{array}{l}0.019499110720 \\
446\end{array}$ & $\begin{array}{l}63.075821091359 \\
620\end{array}$ \\
\hline Wariancja & $1.95450 \mathrm{e}+03$ & 0.0011449397 & 0.0015947756 & $3.75383950 \mathrm{e}-04$ & 0.0016299513 & $3.80212145 \mathrm{e}-04$ & $3.978549208 \mathrm{e}+03$ \\
\hline
\end{tabular}


Tabela 2: Uzyskane wyniki dla eksperymentu 2

\begin{tabular}{|c|c|c|c|c|c|c|c|}
\hline & $\begin{array}{l}\text { Fourier } \\
\text { Transform } \\
50\end{array}$ & $\begin{array}{l}\text { Fourier } \\
\text { Transform } \\
100\end{array}$ & $\begin{array}{l}\text { Binary } \\
\text { Threshold } 50\end{array}$ & $\begin{array}{l}\text { Binary } \\
\text { Threshold } 100\end{array}$ & Kernel 50 & Keinel 100 & $\begin{array}{l}\text { Stacja } \\
\text { pomiarowa }\end{array}$ \\
\hline $\begin{array}{l}\text { Wartość } \\
\text { minimaha }\end{array}$ & 0.00375579 & $\begin{array}{l}4.3981500000 \\
00000 \mathrm{e}-04\end{array}$ & 0.00103944 & $\begin{array}{l}3.07527000000 \\
0000 \mathrm{e}-05\end{array}$ & 0.00108864 & $\begin{array}{l}1.59914000000 \\
0000 \mathrm{e}-04\end{array}$ & 40.7 \\
\hline $\begin{array}{l}\text { Wartość } \\
\text { maksymalna }\end{array}$ & 0.15886 & 0.0927315 & $\begin{array}{l}0.15113100000 \\
0000\end{array}$ & 0.0861874 & 0.156611 & 0.0761252 & 179 \\
\hline Mediana & 0.017037 & 0.0060706 & 0.012215 & 0.00320443 & 0.0125901 & 0.00332129 & 70.2 \\
\hline Średnia & $\begin{array}{l}0.02974952 \\
6197183\end{array}$ & $\begin{array}{l}0.0105882388 \\
02817\end{array}$ & $\begin{array}{l}0.02211532957 \\
7465\end{array}$ & $\begin{array}{l}0.00695989167 \\
6056\end{array}$ & $\begin{array}{l}0.02206378183 \\
0986\end{array}$ & $\begin{array}{l}0.00684563109 \\
8592\end{array}$ & $\begin{array}{l}83.705633802816 \\
900\end{array}$ \\
\hline Moda & 0.00869213 & $\begin{array}{l}4.3981500000 \\
00000 \mathrm{e}-04\end{array}$ & 0.00656262 & 0.00388099 & 0.00108864 & $\begin{array}{l}2.39871000000 \\
0000 \mathrm{e}-04\end{array}$ & 52.3 \\
\hline $\begin{array}{l}\text { Odchylenie } \\
\text { standardowe }\end{array}$ & $\begin{array}{l}0.02817434 \\
8763095\end{array}$ & $\begin{array}{l}0.0143476974 \\
51317\end{array}$ & $\begin{array}{l}0.02600748984 \\
4578\end{array}$ & $\begin{array}{l}0.01239074681 \\
1494\end{array}$ & $\begin{array}{l}0.02635542582 \\
3182\end{array}$ & $\begin{array}{l}0.01114538668 \\
4290\end{array}$ & $\begin{array}{l}35.702772550697 \\
524\end{array}$ \\
\hline Wariancja & $\begin{array}{l}7.93793928 \\
2245211 \mathrm{e}- \\
04\end{array}$ & $\begin{array}{l}2.0585642215 \\
45275 \mathrm{e}-04\end{array}$ & $\begin{array}{l}6.76389528015 \\
8524 \mathrm{e}-04\end{array}$ & $\begin{array}{l}1.53530606546 \\
5514 \mathrm{e}-04\end{array}$ & $\begin{array}{l}6.94608470321 \\
2352 \mathrm{e}-04\end{array}$ & $\begin{array}{l}1.24219644342 \\
3580 \mathrm{e}-04\end{array}$ & $\begin{array}{l}1.2746879678068 \\
41 \mathrm{e}+03\end{array}$ \\
\hline
\end{tabular}

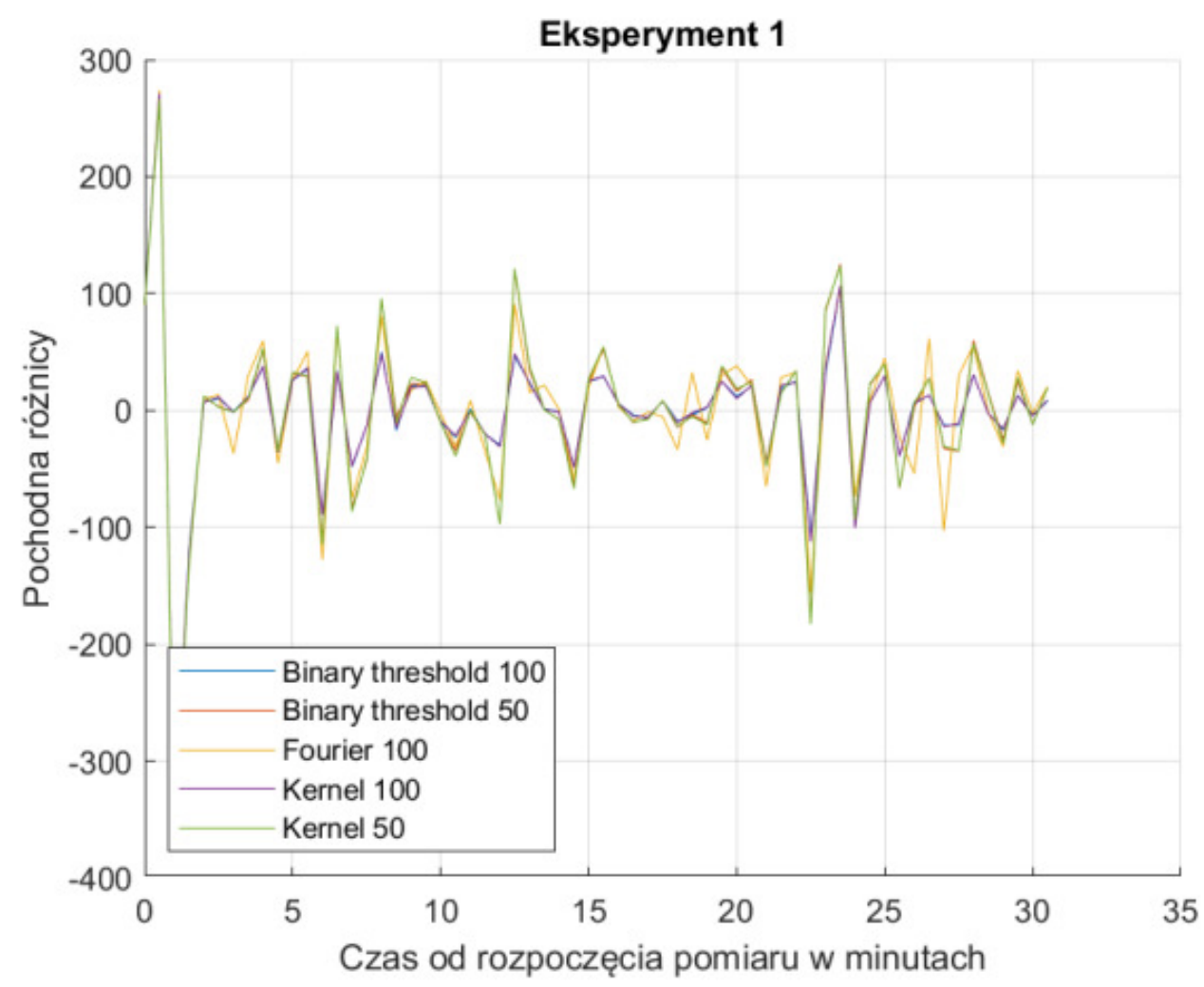

Rysunek 8: Wykres przedstawiający pochodną różnicy wartości pomiędzy pomiarami z aplikacji i stacji pomiarowej wykonanymi w ramach eksperymentu $\mathrm{nr} 1$ 


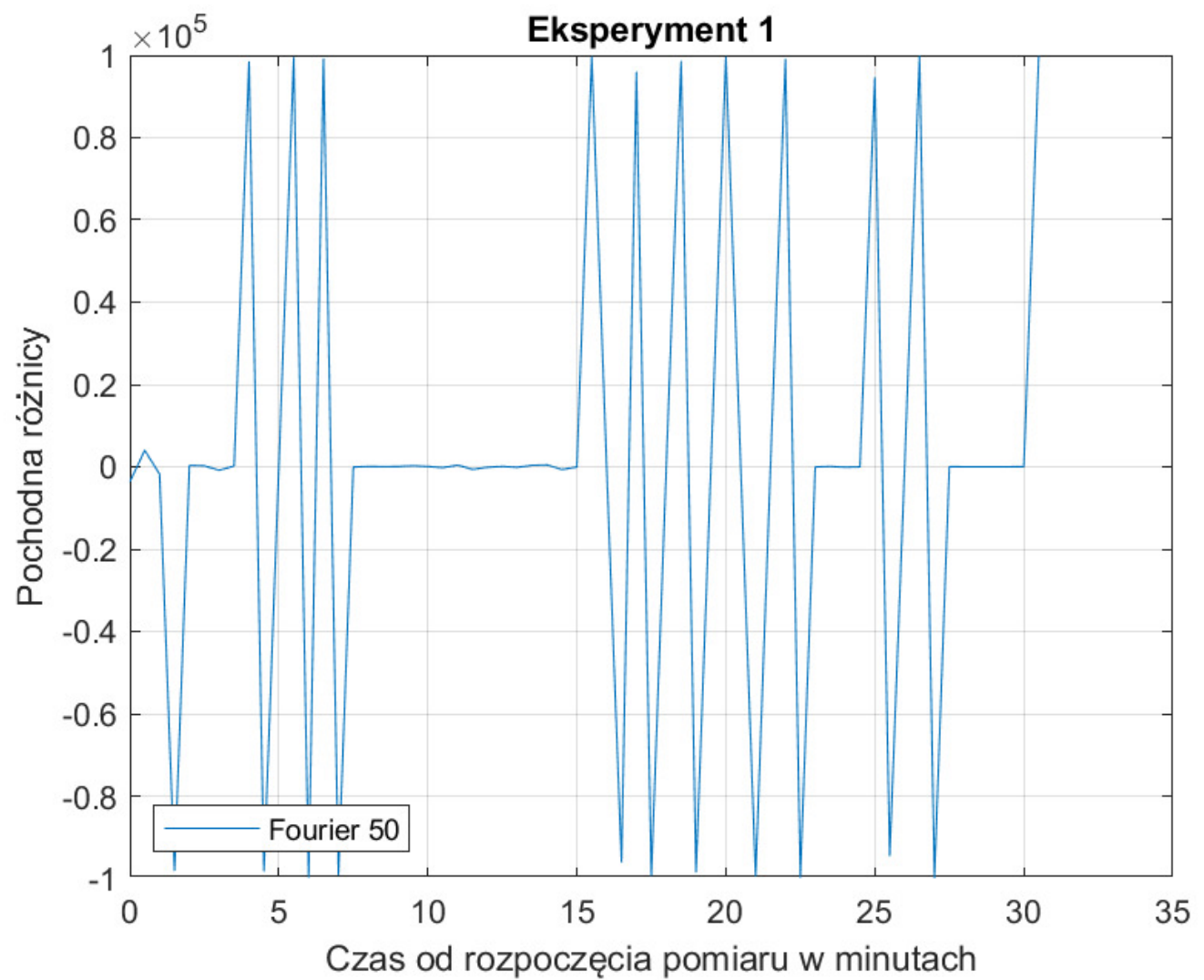

Rysunek 9: Wykres przedstawiający pochodną różnicy wartości pomiędzy pomiarem metody Fourier 50 i stacją pomiarową w ramach eksperymentu 1

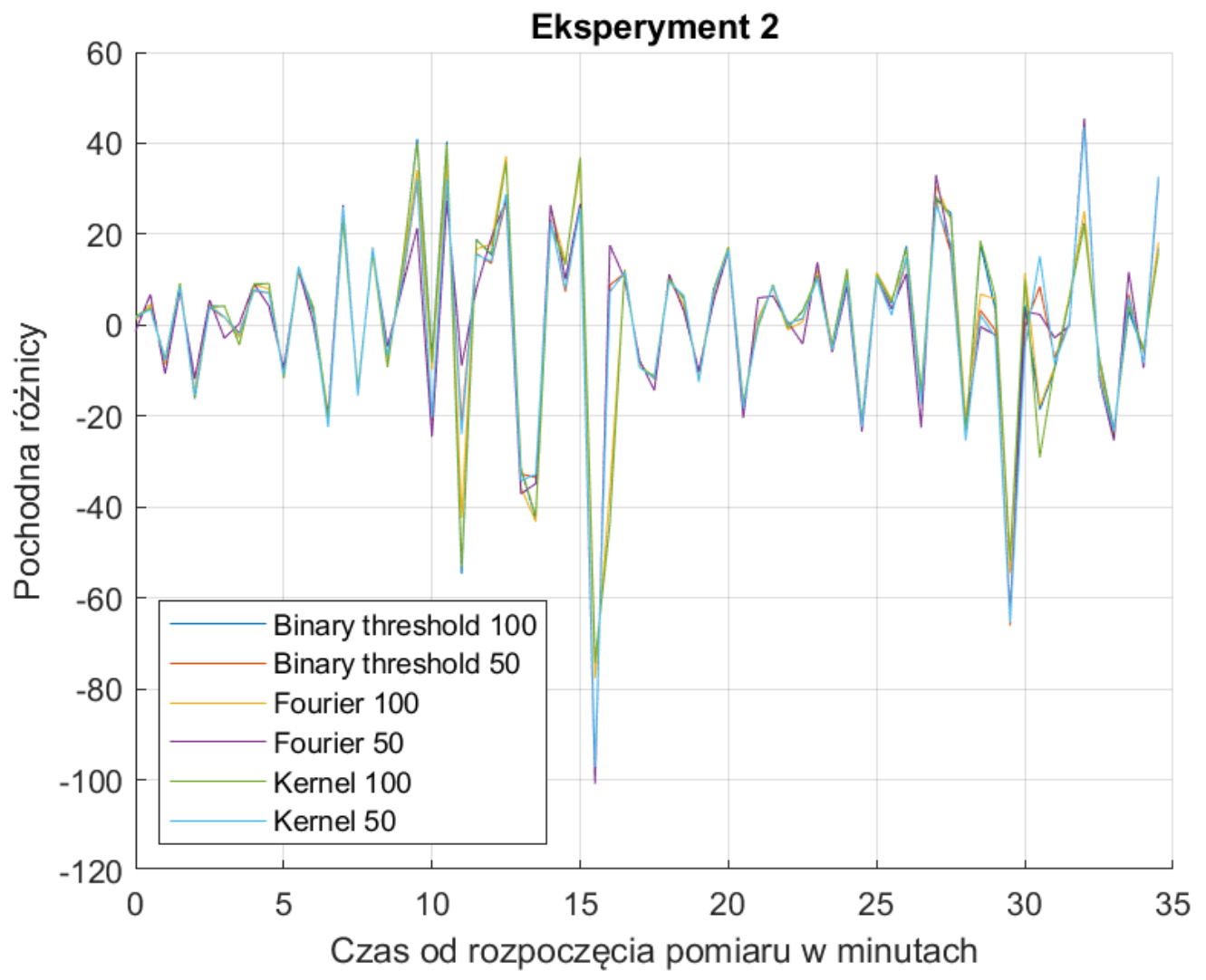

Rysunek 10: Wykres przedstawiający pochodną różnicy wartości pomiędzy pomiarami z aplikacji i stacji pomiarowej 
Tabela 3: Wyniki korelacji Kendalla

\begin{tabular}{|cc|}
\hline Nazwa metody & Wartość korelacji Kendalla \\
\hline Binary threshold $100 \mathrm{Ex} 1$ & 0,0097 \\
Binary threshold $100 \mathrm{Ex} 2$ & 0,4254 \\
Binary threshold $50 \mathrm{Ex} 1$ & 0,099 \\
Binary threshold $50 \mathrm{Ex} 2$ & 0,5615 \\
Fourier $100 \mathrm{Ex} 1$ & $-0,1061$ \\
Fourier $100 \mathrm{Ex} 2$ & 0,5062 \\
Fourier $50 \mathrm{Ex} 1$ & $-0,2281$ \\
Fourier $50 \mathrm{Ex} 2$ & 0,601 \\
Kernel $100 \mathrm{Ex} 1$ & 0,0067 \\
Kernel $100 \mathrm{Ex} 2$ & 0,4713 \\
Kernel $50 \mathrm{Ex} 1$ & 0,0866 \\
\hline
\end{tabular}

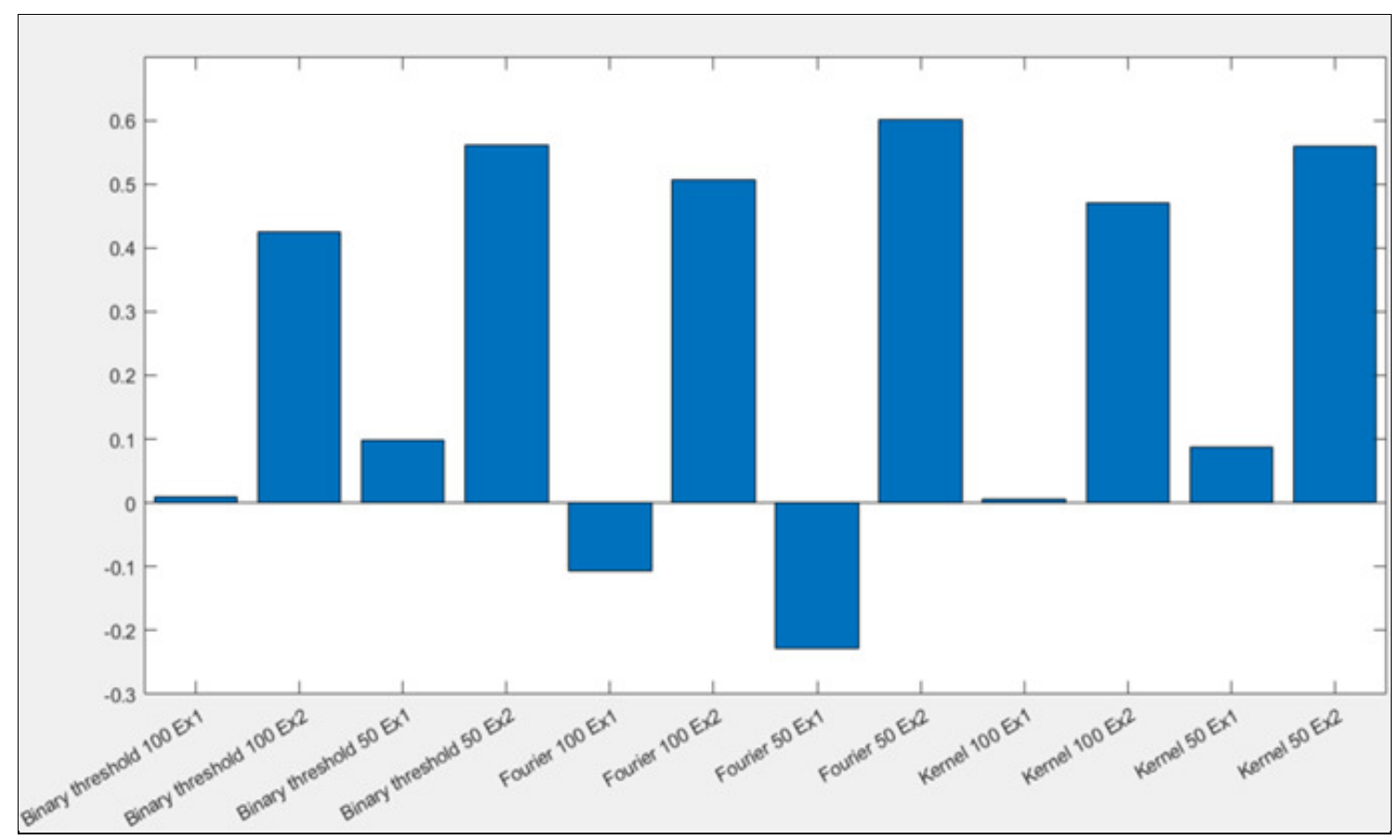

Rysunek 11: Wartości korelacji Kendalla wyników pomiarów poszczególnych metod z wynikami ze stacji pomiarowej

\section{Wnioski}

W niniejszym artykule poruszono zagadnienie popularnego tematu jakim jest zanieczyszczenie powietrza. Przed badaniami autorzy spodziewali się, że metoda Binary threshold z wartością progowania wynoszącą 50 pozwala uzyskać wyniki najbardziej zbliżone z wynikami ze stacji pomiarowej.

Korzystając z powyższych informacji, o wykresach przedstawionych na rysunkach 8,9 oraz 10 można powiedzieć, że:

- $\quad$ wyniki pomiarów każdej z metod posiadają duży rozrzut wartości tuż po rozpoczęciu badań, w przedziale ok. 0 - 2 min.;

- $\quad$ wykresy w przeważającej mierze oscylują wokół osi OX w zakresie wartości od -100 do 100;

- $\quad$ wykresy pochodnych metod Kernel 100 i Binary threshold 100 przebiegają niemal identycznie;
- wykresy pochodnych metod Kernel 50 i Binary threshold 50 są do siebie bardzo zbliżone;

- $\quad$ wykresy Kernel 50 i Binary threshold 50 osiągają najmniejsze wartości skrajne.

Powyższe stwierdzenia potwierdzają wnioski, że wyniki z metody Binary threshold 50 najbardziej zbliżone są do wyników ze stacji pomiarowej.

Analizując dane liczbowe oraz wykres słupkowy, przedstawiony na rysunku 11, można stwierdzić, że:

- $\quad$ wyniki uzyskane z wykorzystaniem metod Binary threshold 100 i Kernel 100 w eksperymencie 1 są najmniej skorelowane z wynikami ze stacji;

- wyniki metody Fourier 50 w eksperymencie 2 są najbardziej zbliżone do wyników ze stacji;

- metody Fourier 100 Ex1 i Fourier 50 w eksperymencie 1 są najbardziej przeciwstawne do wyników ze stacji; 
- metody Binary threshold 50 i Kernel 50 w eksperymencie 2 wykazały się niewiele mniejszą korelacją od metody Fourier 50;

- $\quad$ metoda Binary threshold 50 okazała się najdokładniejsza, ze względu na największą sumaryczną wartość korelacji z obu eksperymentów;

- $\quad$ średnia arytmetyczna korelacji dla eksperymentu 2 wynosi 0,52 , zaś dla eksperymentu 1 wynosi 0,02 ;

- metody z wartością progowania 50 lepiej sprawdziły się w eksperymencie 2;

- metody Fourier 50 i Fourier 100 posiadają największą rozbieżność pomiędzy eksperymentem 1 i 2.

- Korelacja Kendalla pozwala jednoznacznie stwierdzić, czy prezentowane metody pozwoliły uzyskać wyniki zbliżone do tych ze stacji pomiarowej. Metoda Fourier 50 nie może być uznana za najlepszą, mimo uzyskania największej wartości korelacji w eksperymencie 2, ze względu na przekłamania w eksperymencie 1 .

Analiza powyższych wniosków wykazała, że najdokładniejszą metodą jest Binary threshold 50, ze względu na najwyższą sumaryczną wartość korelacji z obu eksperymentów. Tym samym hipoteza postawiona przez autorów została potwierdzona.

\section{Literatura}

[1] A. Kaehler, G. Bradski: OpenCV 3. Kompute-rowe rozpoznawanie obrazu w $\mathrm{C}++$ przy użyciu biblioteki OpenCV.

[2] J. Chwastowski, K. Korcyl (red.): Wybrane zagadnienia przetwarzania obrazu, Kraków Wydawnictwo PK 2014.

[3] W. K. Pratt: Digital Image Processing, PIKS Inside, Willey, 2001.

[4] R. Tadeusiewicz, P. Korohoda: Komputerowa analiza i przetwarzanie obrazów, Wydawnictwo Fundacji Postępu Telekomunikacji, Kraków 1997.

[5] J. Miałdun: Wykorzystanie transformacji fouriera do filtracji szumu informacyjnego z obrazów fotolotniczych, Archiwum Fotogrametrii, Karto-grafii i Teledetekcji 2012.

[6] W. Malina, S. Ablameyko, W. Pawlak: Podstawy cyfrowego przetwarzania obrazów, Akademicka Oficyna Wydawnicza EXIT, Warszawa, 2002.

[7] Dokumentacja OpenCV, https://docs.opencv.org/ master/d9/df8/tutorial_root.html [11.2019].

[8] Wykład „Image filtering” http://mstrzel.eletel.p.lodz.pl /mstrzel/pattern_rec/filtering .pdf [04.2020]. 